\title{
An analysis on fraud tendency of village government officials
}

\author{
Herlina Rahmawati Dewi*, Mahmudi, Rafiq Maulana \\ Department of Accounting, Universitas Islam Indonesia, Yogyakarta, Indonesia \\ *Corresponding author email: herlina.rd@uii.ac.id
}

\section{A R T I C LE I N F O}

Article history:

Available online

\section{Keywords:}

Information asymmetry, religiosity,

organizational culture, regulatory

enforcement, fraud

DOI:

https://doi.org/10.20885/jaai.vol25.i

ss1.art4
A B S T R A C T

This research aims to analyze the influence of information asymmetry, religiosity, organizational culture, and regulatory enforcement toward fraud tendency of village government officials. This study employed a survey approach as the method to obtain data. Regression analysis was used to test the proposed hypotheses. From seventy-one respondents working as village government administrators in thirty-five villages in Magetan Regency, East Java Province, this study has found that information asymmetry, religiosity, organizational culture, and regulatory enforcement significantly affect the village government officials' tendency to commit fraud.

\section{Introduction}

The success of a country's development can be seen from the developments in each sector. One of the indicators in the successful development of a country is its village ability to grow (Wartaekonomi.co.id, 2019). Village as a part of regional autonomy structure has immediate hierarchical position to the community in providing public services. With the issuance of Law No. 6/2014 (Village Act), village has a very strategic role in the government. Considering that village is the smallest unit of government structure, it has a fundamental role for the state. This law makes village start a new phase as well as face the challenges in the regional structuring and development (Yansen, 2014). The regulation also brings new hope, spirit, and sense of self-sufficiency for the village community and government (Kurniawan, 2015).

The stigma that village was originally only used as an object of development has changed, and village has turned into the front-line subject of development, empowerment, and improvement for the community welfare. Recently, village governments have received funds from various sources, such as the central government budget, provincial budget, regency budget, and CSR funds from private sectors. In fact, Village Fund (Dana Desa), which is from the central government budget, continues to increase from Rp20.67 trillion in 2015 to Rp46.98 trillion in 2016 to Rp60 trillion in 2017 and 2018, and it keeps increasing to Rp70 trillion in 2019, and to Rp72 trillion in 2020. The implementation of the Village Act gives an opportunity to realize a village into an entity that, although small, is independent with a self-governing community and local self-government (Jatmikowati \& Suroso, 2016). This act reopens the authority of village government to manage its own financial and development programs.

Village apparatus is assumed to have low capacity in implementing this law since the human resources in village are unequal compared to those of the city (Yuliani et al., 2010). This condition will create the risk of errors and irregularities in the management of village funds. The risks in managing village fund arise because of the village officials' weak administrative skills and governance capacity, unreliable accountability system, lack of supervisory institutions, and local community's lack of critical power. Village government officials are responsible for managing financial transparency, accountability, and freedom from abuse of power. They must also account for the results to the community as the mandate provider.

With such vulnerable conditions, fraud becomes one of the problems with the highest chance of arising. According to Sukanto (2009), fraud is a form of deliberate deception that results in other party's loss and benefits the perpetrator and his groups. Fraud is a crime that includes a variety of human shrewdness in which an individual takes advantage of another individual through existing opportunities (Harry et al., 2017; Singleton et al., 2010).

Fraud thrives due to a complicated bureaucratic system, a relatively complex organizational structure, an unethical organizational culture, ineffective control, and high pressure. Furthermore, the tendency of doing fraud is also ignited by weak enforcement of regulations. Until now financial fraud is still the biggest problem for the government and society. In the context of village financial fraud, the Corruption Eradication Commission (KPK) in 2015 found 14 potential mismanagement cases of village funds rooted from regulatory and institutional aspects, 
governance, supervision, and human resources (Sindonews.com, 2015). Meanwhile, ICW (Indonesia Corruption Watch) found 181 corruption cases of village funds with 184 corruption suspects and a loss of IDR 40.6 billion (Kompas.com, 2018).

Several studies on the implementation of village fund management in Magetan Regency showed that the village government officials attempted to exercise integrity, accountability and transparency in managing the village fund to improve the village economy (Agustiningrum et al., 2020; Juliana \& Widhianningrum, 2017; Kirowati et al., 2017; Ubaidillah, 2019; Zulaikah et al., 2018). The studies also showed that the accountability on the programs related to village fund management was quite good, but still less efficient in the financial accountability. Agustiningrum et al. (2020) found that the village fund realization reached an average of $77 \%$ to $100 \%$. However, the use of the village fund for community empowerment only reached $10 \%$ since the realization of village fund only focused on the development of infrastructure. However, the use of village funds for infrastructure was not accompanied with good transparency (Zulaikah et al., 2018) and even misused by some village officials. For example, the most recent case of the village fund misuse for development projects was the one perpetrated by the Village Head of Baleasri, Magetan Regency, which cost the state more than 248 million rupiahs (Kompas.com, 2020). The contradiction between the study results and the facts of fraud cases in Magetan Regency raises the question of this research: What factors influence the occurrence of village financial fraud?

Research on fraud that occurs in village is still rarely conducted. Few studies, including that conducted by Adi et al. (2016), have revealed that many factors influence the tendency to commit fraud, such as information asymmetry which has a significant effect on fraud in the government sector. Information asymmetry is a condition in which the information is disconnected between the owner of the information and the information recipient (Wilopo, 2006). The previous research tested the effects of information asymmetry on fraud at the local government service level, whereas, this study examines the similar aspect at the village government level since as above mentioned that the research on this topic at the village government level is still very limited.

Another factor that also plays a role in fraud is enforcement of regulations, as that was found by Yuliani et al. (2010). Enforcement of regulations is crucial because Indonesia is a constitutional state so that all the actions of civil servants must adhere to the prevailing laws. The next factor that influences the occurrence of cheating is religiosity. Religiosity is a belief, values, and rules that are transcendental. In an organizational context, Weaver and Agle (2002) explain that religiosity has two roles: self-identity and a motivational orientation that will influence behavior.

The research related to the influence of religiosity on fraud was conducted previously by Adi et al. (2016), Asrori (2014), Chandra (2015), Urumsah et al. (2018), and Wilopo (2006). However, this research was not conducted in the context of village government. Therefore, this study explores the factors that influence the village officials to commit fraud in village financial management. The research problem posed is whether information asymmetry, religiosity, organizational culture, and regulation enforcement affect fraud in village government. Knowing the factors that might affect the government officials in committing financial fraud specifically in the village scope will give a theoretical contribution in the field of good governance. Furthermore, the government could practically benefit from the research by implementing its results to develop a program that increases the official's integrity and knowledge to manage the village fund in more accountable and transparent manner.

\section{Literature Review}

\section{Implementation of Village Administration}

Law No. 6/2014 (the Act Village) has given a new view of village as a legal entity or community unit that administers governance, regulates, and manages its own territorial affairs independently. Village government involves a village head or that referred to by another name, assisted by village officials as an element of village administration. Due to the proximity of village political stage, the community can normatively participate in the village governance and development process.

A village head is the representative of a village government. A village head is considered as a role model or figure who gets legitimacy to manage a territory. This legitimacy does not necessarily give the village head full power to carry out village governance in absolute terms. There are a number of requirements to implement good village governance under the Village Act, namely legal certainty, orderly governance, orderly public interest, openness, professionalism, accountability, effectiveness and efficiency, local wisdom, diversity, and participation.

\section{Theory of Planned Behavior (TPB)}

Theory of Planned Behavior (TPB) is a theory that explains the reasons behind an individual action or behavior (Ajzen, 1991). Urumsah et al. (2016) explain that the TPB can be used to analyze an individual ethical and unethical behavior in several contexts. TPB is often used to explain unethical behavior conducted by individual. TPB explains that before someone takes an action, an intention precedes his behavior. Ajzen (1991) describes three main factors for an 
individual to behave, i.e. attitude toward the behavior (attitude), subjective norms, and perceived behavioral control. These three factors influence the individual intention to conduct a certain action which then lead to actual behavior.

\section{Agency Theory}

Agency theory assumes that all individuals act on their own interests. An agency relationship can exist when one party (principal) agrees to use another party (agent) to perform several services. In a village governance, an agency relationship occurs between a community as the principal and village government as the agent. The community as the principle gives mandate to the village government as the agent to manage village resources including financial resources to pursue wealth, prosperity, and utility for the village community.

Agency theory is based on several postulates, which are categorized into into three, namely human nature, organization, and information (Eisenhardt, 1989). The fundamental assumption of human nature is that humans are selfish, rationally limited, opportunistic, and do not like risks.

\section{Fraud Triangle Theory}

A big problem in the world that has been a legacy for generations is corruption (Prabowo, 2014). Fraud that occurs is not a spontaneous act. There are three elements or conditions that underlie a perpetrator in committing fraud those are pressure, opportunity, and rationalization (Tuanakotta, 2007). These three elements are known as the fraud triangle. The fraud triangle was first introduced by (Cressey, 1953). Until now the fraud triangle is often used to explain the factors that cause an individual to commit fraud. Fraud triangle theory has been applied in several research contexts, including governmental sector.

In many developing countries with weak regulatory enforcement and a lack of understanding of good governance, corruption is one of the most common types of fraud. Corruption in Indonesia has long been a culture, from central to regional levels. The corruption that occurs has not been considered as a threatening crisis alarm. Moreover, Prabowo and Cooper (2016) find that corruption is regular since the New Order era. Failed bureaucracy or organization, lack of community involvement, and disharmony between law enactment and public demand are seen as the reasons for the proliferation of corruption (Atmadja \& Saputra, 2017).

Corruption in the government will indirectly deprive the public rights to health, education, and access to other public services. Based on the existing types, corruption is a type of fraud that is difficult to reveal because it forms a symbiotic mutualism, which is usually done by more than one party by working and enjoying the results together (Maghfiroh et al., 2015).

\section{Hypothesis Development}

\section{Effect of information asymmetry on tendency of fraud}

Based on the Agency theory, there is an agency problem that arises from the relationships between the agent and the principal. Agency problem occurs because of information asymmetry which is a condition where there is an imbalance of information obtained by the principals and agents (Permatasari et al., 2017). Such conditions give rise to the potential of fraud to be perpetrated by presenting unsuitable information for personal gain that may harm other parties. Meanwhile, the community as the principal needs the information provided by the government as a form of government responsibility in running the government administration. Wilopo's (2006) and Chandra's (2015) research show that information asymmetry positively influences fraud. Based on the description, this study assumes that the existence of information asymmetry between the community and the village government officials will trigger the tendency to commit fraud, thus hypothesis proposed is as follows.

$\mathrm{H}_{1}$ : The higher the level of information asymmetry, the higher the village officials' tendency for committing fraud.

\section{Effect of religiosity on tendency of fraud}

Based on the Theory of Planned Behavior, an individual intention to behave is affected by attitude, subjective norms, and perceived behavioral control. Subjective norms as one of the elements root from the religious norms that an individual embraces, so, religiosity is also an important factor that will determine the individual subjective norms. Glock and Stark (1965) define religiosity as an integrated system of beliefs, lifestyle, ritual activities, and institutions that give meaning in life and guide humans to sacred values or the highest values. Religious attitudes play a significant role in shaping individual and group characters and are believed to influence behavior, ways of thinking, and also how to behave with others (Urumsah et al., 2016).

Basri (2015) assumes that the high level of religiosity can protect someone from engaging in unethical behavior, thereby reducing the tendency to commit fraud. Moreover, the research result shows a negative influence of religiosity on fraud. Thus, this research proposes the second hypothesis as follows.

$\mathrm{H}_{2}$ : The higher the level of religiosity of village officials, the less likely they are to commit fraud. 


\section{Influence of organizational culture on tendency of fraud}

Organizational culture refers to a set of assumptions or beliefs carried and spread by organizational members (Hoque et al., 2013). Organizational culture consists of organizational vision, values, norms, beliefs, systems, symbols, language, assumptions, and habits (Needle \& Burns, 2019). In addition, organizational culture affects the way people in the organization interact with each other and with the stakeholders. Hence, organizational culture will determine how much employees identify themselves to the organization. Humans and culture are two factors that are interrelated, inseparable, interact with each other, continue to work together, and affect one another. In general, an individual's behavior can be in the form of ethical behavior or unethical behavior. These behaviors can be influenced by organizational culture and leadership. The previous research shows that organizational culture negatively influences the tendency to fraud (Mihret, 2014). Based on these considerations, the third hypothesis is stated as follows.

$\mathrm{H}_{3}$ : The better the organizational culture, the lower the village officials' tendency to commit fraud

\section{Effect of law enforcement on tendency of fraud}

The theory explaining the relationships between law enforcement and crime can be found in the studies of Becker (1968) and Garoupa (1997). In 1968, Becker wrote a seminal paper on crime and law enforcement, and Garoupa (1997) extended Becker's work by developing a theoretical model of optimal law enforcement. The core result of Becker's research stated that the probability and the severity of punishment would deter crime. The consequences of Becker's theory are that the fine should be maximum since it is a costless transfer, whereas the probability of detection and conviction is costly. In law enforcement theory, there is a deterrence hypothesis asserting that people will respond to the deterring incentives created by the criminal justice system. Based on this theory, fraud thus can be eliminated by having severe punishment imposed on the fraudster. In relevance to theory of law enforcement, this study posits the argument that the strength of law enforcement will deter fraud in village government.

Law enforcement is a real action by legal subjects to the applicable law, namely by obeying the existing laws in a country to guarantee, maintain, and arrange the relations that occur between the elements of the state. Thus, an effective enforcement of regulations depends on the legal subjects' law enforcement efforts to ensure that the regulations applied appropriately.

Chandra (2015) found that law enforcement had a negative effect on the government sector. Besides, the research results of Yuliani et al. (2010) show that the enforcement of regulations has a significantly negative effect on fraud in the government sector. Accordingly, this research proposes the fourth hypothesis as follows.

$\mathrm{H}_{4}$ : The stricter the enforcement of regulations, the less likely the village officials are to commit fraud

\section{Research Method}

\section{Sample}

This study used a quantitative research approach. The type of data in this study is primary data which were obtained directly from the primary data sources, The data were collected using questionnaires distributed to the village government circle in Magetan Regency. This research selected Magetan Regency because of the contradiction captured between the previous study results (Agustiningrum et al., 2020; Juliana \& Widhianningrum, 2017; Kirowati et al., 2017; Ubaidillah, 2019; Zulaikah et al., 2018) and the facts of fraud cases in this regency (Kompas.com, 2020). Convenience sampling method was used for data gathering.

Magetan is one of the districts in East Java Province, located at the western end of the province. Magetan Regency has an area of 688.85 square kilometers and is one of the smallest districts in East Java. Administratively, Magetan Regency consists of 18 sub-districts, 208 villages, and 27 wards. Magetan is one of Indonesia's districts whose villages also implement Law No. 6/2014 (Village Act). In 2019 the Village Fund allocated for Magetan Regency reached 167.71 billion rupiahs. Harianto (2019) states that in 2019, 51 villages in Magetan were fraudfragile related to the village fund use.

\section{Variable Definition and Measurement}

This research has one dependent variable and four independent variables. These variables were measured using a Likert scale with the interval of 1 to 4 where (1) indicated strong disagreement up to (4) demonstrating strong agreement.

\section{Dependent Variable}

Tendency for an employee to commit fraud is a condition when the employee has the motivation and opportunity to commit act of cheating in his work environment, which is done deliberately for personal gain but does not benefit those around them. Fraud can be in the forms of corruption, misuse of assets, and financial report falsification. 
This variable is measured by nine questions developed by Association of Certified Fraud Examinations (ACFE) with the indicators including corruption, misuse of assets, and fraudulent financial statements (Najahningrum, 2013). The measurement of this variable in this research used a Likert scale of 1 - 4, where (1) meant strongly disagree up to (4) which meant strongly agree. The higher the indicated value, the higher the tendency for fraud to occur.

\section{Independent Variables}

Information asymmetry is a condition where there is a gap in information between the party who owns or provides the information and those who need or receive the information which opens up an opportunity to commit fraud by taking the advantage out of this information gap.

The measurement of information asymmetry was adopted from the measurement model developed by Dunk (1993), which was also employed by Wilopo (2006). The questionnaire to measure this variable consisted of five questions related to vertical asymmetry, namely the information gap between superiors and subordinates. Likert scale of $1-4$ in which (1) indicated strong disagreement until (4) demonstrating strong agreement was used with to measure the respondents' responses.

According to McDaniel and Burnett (1990), the definition of religiosity is the belief in God accompanied by a commitment to carry out and follow all religious principles established by Almighty God. Meanwhile, Pamungkas (2014) defines religiosity as an integrated system of beliefs, lifestyle, ritual activities, and institutions that give meaning to an individual's life and direct the individual to sacred values or the highest values. The instrument used to measure religiosity consisted of four questions developed by Pamungkas (2014). The respondents' responses in this research were gauged using a 4-point Likert scale, where (1) meant strongly disagree until (4) which showed strong agreement.

Organizational culture is a set of behaviors carried out repeatedly, which is then studied, developed, and finally becomes a reference for running the organization operations to fit the organizational plan. Organizational culture was measured using the instruments used in Najahningrum (2013). There were four questions to measure organizational culture using Likert scale of 1 (strongly disagree) - 4 (strongly agree). If the value shown was higher, the organizational culture will be more ethical.

Regulatory enforcement is an effort to uphold legal norms as a basis for behaviors or relationships in social and state life. The enforcement of regulations is hoped to reduce all unethical behaviors in social life. The instrument used to measure regulatory enforcement consisted of five questions developed by Zulkarnain (2013). Likert scale of $1-4$, (1) indicating strong disagreement until (4) signifying strong agreement, was used to measure the respondents' responses.

\section{Data Quality Test}

To test the data quality of this study, the validity and reliability tests were conducted. Validity test was done by examining each item variable significance value in correlation with the total construct score. The variable indicator can be said to be valid if the significance value is $<0.05$. Simultaneously, the variable can be said to be reliable if the Cronbach Alpha value is $\geq 0.60$.

\section{Data Analysis}

Multiple regression analysis was used to analyze the relationships between the variables of this study. In this model, multiple regression test included testing the coefficient of determination and t-test. The determinant coefficient test is to explain the ability of the independent variable to explain the dependent variable. The t-test is carried out to test the hypotheses that have been formulated.

\section{Results and Discussion}

\section{Respondent Characteristics}

The primary data were obtained by the questionnaires distributed to the village officials in Magetan Regency. The number of initial questionnaires distributed was 85, but 11 questionnaires were not returned. Moreover, three of the 74 questionnaires that were returned were incomplete resulting in only 71 questionnaires eligible for further processing. There were 31 male respondents and 40 female respondents who participated in this research. The minimum age of the respondents was 22 years, and the maximum was 60 years. The age distribution of the respondents was dominated by respondents aged 31 to 50 years. On average, the respondents served as head of affairs, with the percentage of $65 \%$, and the education level of most respondents was undergraduate. 
Table 1. Respondent Characteristics

\begin{tabular}{lcc}
\hline Characteristics & Number & $\%$ \\
\hline Gender & 31 & \\
$\quad$ - Male & 40 & $44.2 \%$ \\
$\quad$ - Female & & $55.8 \%$ \\
Education & 30 & \\
$\quad$ - High school/equivalent & 3 & $42.3 \%$ \\
- Diploma & 35 & $4.2 \%$ \\
- Bachelor degree & 3 & $49.3 \%$ \\
- Postgraduate degree & & $4.2 \%$ \\
Age & 4 & \\
- 21 - 30 & 25 & $5.6 \%$ \\
- 31 - 40 & 29 & $35.2 \%$ \\
- 41 - 50 & 13 & $40.8 \%$ \\
- 51 - 60 & & $18.3 \%$ \\
Tenure & 39 & \\
- - 10 years & 20 & $54.9 \%$ \\
- 11 - 20 years & 10 & $28.2 \%$ \\
- 2 1 - 30 years & 2 & $14.1 \%$ \\
- 31 - 40 years & & $2.8 \%$ \\
Position & 5 & \\
- Village Head & 7 & $6.9 \%$ \\
- Village Secretary & 47 & $65.5 \%$ \\
- Head of Affairs & 12 & $17.2 \%$ \\
- Treasurer & &
\end{tabular}

Based on the results of descriptive statistics, it can be seen that the variable of tendency for cheating had the minimum value of 1.00 and maximum value of 3.11. At the same time, the mean value was 1.8186 with the standard deviation value 0.57490 . The information asymmetry variable showed the minimum value of 1.80 and maximum value of 4.00 with the mean value 2.8423 and standard deviation value 0.53763 . The minimum, maximum, mean, and standard deviation values of religiosity were 3.00, 4.00, 3.6021, and 0.37459 respectively. The organizational culture variable had the minimum value of 2.25 and maximum value of 4.00 with the mean and standard deviation values 3.1232 and 0.45684 sequentially. The rule enforcement variable showed the minimum value of 2.00 and maximum value of 3.80 with the mean value 2.6563 and standard deviation value 0.39883 . The results of descriptive statistics can be seen in Table 2 .

Table 2. Descriptive Statistics

\begin{tabular}{lccccc}
\hline & $\mathrm{n}$ & Minimum & Maximum & Mean & Std. Dev. \\
\hline Asymmetry Information & 71 & 1.80 & 4.00 & 2.8423 & 0.53763 \\
Religiosity & 71 & 3.00 & 4.00 & 3.6021 & 0.37459 \\
Organizational Culture & 71 & 2.25 & 4.00 & 3.1232 & 0.45684 \\
Regulatory Enforcement & 71 & 2.00 & 3.80 & 2.6563 & 0.39883 \\
Fraud & 71 & 1.00 & 3.11 & 1.8168 & 0.57490 \\
\hline
\end{tabular}

\section{Validity and Reliability Tests}

Validity testing can be done by examining each item variable significance value in correlation to the total construct score. The item is considered valid if the significance value is $<0.05$. Based on the validity test, all the questions were deemed valid because they showed the significant values below 0.05 .

Reliability relates to the accuracy of the measuring instruments or questionnaires in a study. The data obtained are reliable if and only if the Cronbach Alpha value is $\geq 0.60$. Based on the results of reliability testing with Cronbach Alpha, the religiosity variable had the Cronbach Alpha value of 0.796; religiosity 0.722; organizational culture 0.730; enforcement 0.643 and fraud 0.939. Because all the variables had the Cronbach Alpha values above 0.60 , all variables met the reliability criteria.

\section{Correlation Test}

Based on the results of the correlation test in Table 3, it is known that the variables of information asymmetry, religiosity, organizational culture, and regulatory enforcement had significant correlations to fraud. Information asymmetry had a positive correlation with fraud with the value $0.469(p<0.01)$; religiosity had a negative correlation with cheating with the value $-0.293(p<0.05)$; organizational culture showed a negative correlation with fraud with 
the value $-0.563(\mathrm{p}<0.01)$; and enforcement of regulations had a negative correlation with fraud with the value $0.521(\mathrm{p}<0.01)$.

Table 3. Correlations Matrix

\begin{tabular}{|c|c|c|c|c|c|c|c|c|c|c|}
\hline & & 1 & 2 & 3 & 4 & 5 & 6 & 7 & 8 & 9 \\
\hline 1 & Gender & 1 & & & & & & & & \\
\hline 2 & Tenure & $0.237 *$ & 1 & & & & & & & \\
\hline 3 & Occupy & 0.129 & $-0.240 *$ & 1 & & & & & & \\
\hline 4 & Edu & -0.188 & -0.080 & 0.009 & 1 & & & & & \\
\hline 5 & Asym & 0.005 & 0.064 & 0.004 & 0.157 & 1 & & & & \\
\hline 6 & Relig & 0.026 & -0.001 & -0.032 & 0.023 & 0.149 & 1 & & & \\
\hline 7 & Culture & $0.246 *$ & -0.059 & 0.063 & -0.056 & $-0.245^{*}$ & $0.249 *$ & 1 & & \\
\hline 8 & Regulate & -0.140 & 0.091 & 0.203 & -0.208 & -0.137 & $0.281 *$ & $0.361 * *$ & 1 & \\
\hline 9 & Fraud & -0.096 & -0.010 & 0.013 & 0.222 & $0.469 * *$ & $-0.293 *$ & $-0.563 * *$ & $-0.521 * *$ & 1 \\
\hline
\end{tabular}

Pearson's bivariate correlations. ${ }^{*}$ sig. $<0.05 ;{ }^{* *}$ sig. $<0.01$

\section{Regression Analysis}

Multiple regression analysis predicts an outcome resulting from two or more independent variables in a linear equation. The results of multiple linear regression equation test using SPSS statistical tools can be seen in Table 4 below.

Table 4. Regression Results

\begin{tabular}{lcccc}
\hline \multicolumn{1}{c}{ Independent Variable } & Hypothesis & $\begin{array}{c}\text { Coefficient } \\
(\beta)\end{array}$ & $\mathrm{t}$ & Sig. \\
\hline Constanta & & 4.090 & 7.021 & 0.000 \\
Information Asymmetry & $\mathrm{H}_{1}(+)$ & 0.405 & 4.388 & 0.000 \\
Religiosity & $\mathrm{H}_{2}(-)$ & -0.284 & -2.099 & 0.040 \\
Organization Culture & $\mathrm{H}_{3}(-)$ & -0.396 & -3.453 & 0.001 \\
Regulation Enforcement & $\mathrm{H}_{4}(-)$ & -0.438 & -3.397 & 0.001 \\
$\mathrm{~F}=21.595 ; p<0,01$ & & & & \\
$\mathrm{R}^{2}=0.567 ;$ Adjusted $\mathrm{R}^{2}=0.541$ & & & & \\
\hline
\end{tabular}

\section{Hypothesis Test Results}

In the regression analysis test, the ability of the independent variables in predicting the variability of dependent variable can be seen from the $R^{2}$ value $(0.567)$ and Adjusted $R^{2}$ value $(0.541)$. This $R^{2}$ value indicates that the independent variables are able to explain the dependent variable as much as $56.7 \%$, while the remaining percentage can be explained by other variables outside this research model.

Based on the results of hypothesis testing using t-test, information asymmetry had a significantly positive effect on tendency for cheating. The regression test results showed that the information asymmetry variable had a regression coefficient of 0.405 with $\mathrm{t}$-value of $4.388(\mathrm{p}<0.01)$. It shows that the higher the level of information asymmetry, the greater the village officials' tendency to commit fraud. Thus, this research first hypothesis is supported.

Meanwhile, the regression coefficient of religiosity variable was $-0.284(t=-2.099 ; p<0.05)$. This result indicates that religiosity has a significantly negative effect on the tendency to commit fraud. It means that the higher the level of religiosity of village officials, the lower the tendency to commit fraud. Based on the result, the second hypothesis of this study is supported.

The regression test result on the third hypothesis indicates that organizational culture has a significantly negative effect on fraud. The regression coefficient of organizational culture variable was $-0.396(t=-3.453 ; p$ $<0.01)$. The result can be interpreted that the better the organizational culture, the lower the village officials' tendency to commit fraud. Based on this, the third hypothesis of this research is supported.

Test on the fourth hypothesis shows that regulatory enforcement has a significantly negative effect on fraud. The regression test result for the variable of rule enforcement resulted in a regression coefficient of -0.438 ( $t$ $=-3.397 ; p<0.01)$. It means that the better the enforcement of regulations, the lower the village officials' tendency to commit fraud. Thus, the fourth hypothesis is also supported.

\section{Discussion}

This study indicates that the higher the level of information asymmetry, the higher the tendency for financial fraud to occur in the village government. Information asymmetry variable had the strongest effect on fraud tendency with a positive direction $(\beta=0.405 ; t=4.388 ; p=0,000)$. The results of this study confirm that agency theory applies 
to the governmental sector, especially in the village government. There is an agency problem arising from the agency relationships between community and village government officials in the form of information asymmetry. The previous research conducted in the business sector has shown consistent results (Ghafoor et al., 2019) that the efforts to reduce information asymmetry through the transparency of public information on village financial management are essential to reduce the level of fraud in the village government.

Religiosity also has a significant role in preventing fraud in village financial management. The effect of religiosity on fraud tendency in village government is strong enough although it is not as strong as the other independent variables that are depicted in the regression analysis results $(\beta=-0.284 ; t=-2,099 ; p=0,040)$. This finding supports the research conducted by Walker et al. (2012) that posits that religiosity can be used to improve ethical judgment. The research by McGuire et al. (2012) shows that the companies operating in the areas with high religiosity levels tend to have lower levels of financial reporting deviation. Thus, the efforts to foster community religiosity and village officials' attitude are relevant to prevent financial fraud in the village government. Individual's religiosity can also be related to Fraud Triangle Theory, especially to rationalization aspect. Religious values cannot be exploited by the fraudsters to legitimate their crime. Fraud and corruption cannot be righted by any religion.

Organizational culture also has a significant influence in preventing fraudulent practices in village financial management $(\beta=-0.396 ; t=-3,453 ; p=0,001)$. Based on the regression analysis, it can be inferred that organizational culture has a negative and significant impact on fraudulent acts in the village government. An organizational culture such as respect for work ethics, performance culture, and conducive work environment significantly influences the realization of a good village financial governance. Mihret (2014) shows that national culture has a significant influence on the risk of fraud. Countries with large power distance and less long-term orientation tend to have a higher risk of fraud. Therefore, democratization at the village government level is essential to improve organizational culture and prevent corruption in the village.

Finally, enforcement of regulations is also a crucial supporting factor in preventing fraud in the village government. The result of this study shows that the variable of regulation enforcement has a very strong effect on the fraud tendency of village government officials with a negative direction $(\beta=-0.438 ; t=-3,397 ; p=0,001)$. In conformance with Fraud Triangle Theory, this research implies that the government should develop a good regulatory system to close the opportunities for village government officials to commit fraud. Completeness and clarity of regulations governing village financial management and accountability are fundamental to good village financial governance. Besides, the strict legal sanctions for village officials who misappropriate the village funds need to be applied as the deterrent effect. The previous research has shown that law enforcement has a vital role in preventing financial crimes (Taylor, 2018).

The results of this study provide a policy implication, especially for the village government, to improve the transparency and enhance the morality of the officials by improving their religiosity, injecting good culture in village government management, and improving law enforcement mechanism. To support these factors in order to to be well-implemented, the local government and the minister of home affair (MOHA) should strengthen good public governance at all levels of government, from the central level to the village governmental level.

\section{Conclusion}

The implementation of Law No. 6/2014 concerning Villages has provided more significant opportunities and authority to village government to manage finances and carry out village development. Along with the increase in village funds managed by the village government, the challenge that must be overcome is how to prevent fraud in the management of village funds. Although hierarchically the organizational structure of a village government seems simple and the number of corruptions in village funds is not as large as the number of corruptions perpetrated by the officials at the district, provincial, and central levels, if this insignificant number of corruptions at the village level is allowed, it will damage the culture of government organization. Therefore, the efforts to prevent fraud in village fund management must be made both systemically and culturally.

This research implies that the efforts to prevent fraud in village funds' systemic management can be carried out by building transparency and enforcement of regulations. Meanwhile, the efforts to prevent the fraud in spatial village fund use can be culturally carried out by fostering the village officials' religiosity and strengthening the organizational culture by implementing the values of democracy, deliberation, cooperation, and work ethics. However, this research data collection was restricted only in Magetan, one regency in East Java province, so it can be a limitation to generalize the research findings. Hence, it can be an opportunity for future research to use the data from a wider range of areas.

\section{References}

Adi, M. R. K., Ardiyani, K., \& Ardianingsih, A. (2016). Analisis faktor-faktor penentu kecurangan (fraud) pada sektor pemerintahan (studi kasus pada dinas pendapatan pengelolaan keuangan dan aset daerah kota Pekalongan). Jurnal Litbang Kota Pekalongan, 10, 1-10. 
Agustiningrum, W., Isharijadi, I., \& Wihartanti, L. V. (2020). Analisis dampak pengelolaan dana desa teradap pemberdayaan masyarakat di kecamatan Magetan kabupaten Magetan. PROMOSI: Jurnal Program Studi Pendidikan Ekonomi, 8(2), 63-69. https://doi.org/10.24127/PRO.V8I2.3311

Ajzen, I. (1991). The theory of planned behavior. Organizational Behavior And Human Decision Processes, 50(2), 179-211. https://doi.org/10.1016/0749-5978(91)90020-T

Asrori, A. (2014). Kapasitas perangkat desa dalam penyelenggaraan pemerintahan desa di kabupaten Kudus. Jurnal Bina Praja, 06(02), 101-116. https://doi.org/10.21787/JBP.06.2014.101-116

Atmadja, A. T., \& Saputra, A. K. (2017). Pencegahan fraud dalam pengelolaan keuangan desa. Jurnal IImiah Akuntansi Dan Bisnis, 12(1), 7-15. https://doi.org/10.24843/JIAB.2017.v12.i01.p02

Basri, M. Y. (2015). Pengaruh dimensi budaya dan religiusitas terhadap kecurangan pajak. Akuntabilitas: Jurnal IImu Akuntansi, 8(1), 61-77. https://doi.org/10.15408/akt.v8i1.2764

Becker, G. S. (1968). Crime and punishment: An economic approach. Journal of Political Economy, 76(2), 169127. https://doi.org/10.1086/259394

Chandra, D. (2015). Determinan terjadinya kecenderungan kecurangan akuntansi (fraud) pada dinas pemerintah kabupaten Grobogan. Accounting Analysis Journal, 4(3), 1-9.

Cressey, D. R. (1953). Other people's money: A study in the social psychology of embezzlement. Patterson Smith.

detikNews. (2019, June 28). Anggaran Alokasi 51 Desa di Magetan Rawan Disalahgunakan. Detik.Com. https://news.detik.com/berita-jawa-timur/d-4603943/anggaran-alokasi-51-desa-di-magetan-rawandisalahgunakan

Dunk, A. S. (1993). The effect of budget emphasis and information asymmetry on the relation between budgetary participation and slack. The Accounting Review, 68(2), 400-410.

Eisenhardt, K. M. (1989). Agency theory: An assessment and review. Academy of Management Review, 14(1), $57-$ 74. https://doi.org/10.5465/amr.1989.4279003

Garoupa, N. (1997). The theory of optimal law enforcement. Journal of Economic Surveys, 11(3), 267-295. https://doi.org/10.1111/1467-6419.00034

Getie Mihret, D. (2014). National culture and fraud risk: exploratory evidence. Journal of Financial Reporting and Accounting, 12(2), 161-176. https://doi.org/10.1108/jfra-10-2012-0049

Ghafoor, A., Zainudin, R., \& Mahdzan, N. S. (2019). Corporate fraud and information asymmetry in emerging markets: case of firms subject to enforcement actions in Malaysia. Journal of Financial Crime, 26(1), 95112. https://doi.org/10.1108/JFC-11-2017-0107

Glock, C. Y., \& Stark, R. (1965). Religion and Society in Tension. Rand McNally Company.

Harry, M., Mulia, K., Febrianto, R., \& Kartika, R. (2017). Pengaruh moralitas individu dan pengendalian internal terhadap kecurangan: Sebuah studi eksperimental. Jurnal Akuntansi Dan Investasi, 18(2), 198-208. https://doi.org/10.18196/jai.180283

Hoque, N., Khan, M. A., \& Mowla, M. M. (2013). Organisational culture: features and framework from Islamic perspective. Humanomics, 29(3), 202-219. https://doi.org/10.1108/H-06-2013-0040

Jatmikowati, S. H., \& Suroso, T. E. (2016). Desa dan legitimasi keberdayaan sosial; telaah implementasi UndangUndang No. 6/2014 tentang desa di kabupaten Malang. Publisia, 1(2), 196-211.

Juliana, P., \& Widhianningrum, P. (2017). Akuntabilitas anggaran pendapatan dan belanja desa Garon kecamatan Kawedanan kabupaten Magetan. Assets: Jurnal Akuntansi Dan Pendidikan, 6(2), 169-183. https://doi.org/10.25273/jap.v6i2.1754

Kirowati, D., Qimyatussa'adah, Q., \& Sugiharto, S. (2017). Penerapan azas pengelolaan keuangan desa (studi kasus $\square$ : Desa Temboro kecamatan Karas kabupaten Magetan). Journal of Applied Managerial Accounting, 1(2), 148-156.

Kompas.com. (2018, November 21). ICW: ada 181 kasus korupsi dana desa, rugikan negara Rp40,6 miliar. Kompas. https://nasional.kompas.com/read/2018/11/21/19000481/icw-ada-181-kasus-korupsi-dana-desarugikan-negara-rp-406-miliar?page=all

Kompas.com. (2020, October 9). Korupsi dana desa Rp248 juta, mantan kades ini dijebloskan ke penjara. Kompas. 
https://regional.kompas.com/read/2020/10/09/11390961/korupsi-dana-desa-rp-248-juta-mantan-kadesini-dijebloskan-ke-penjara

Kurniawan, B. (2015). Desa Mandiri, Desa Membangun. Kementerian Desa, Pembangunan Daerah Tertinggal, dan Transmigrasi Republik Indonesia.

Maghfiroh, N., Ardiyani, K., \& Syafnita. (2015). Analisis pengaruh financial stability, personal financial need, external pressure, dan ineffective monitoring pada financial statement fraud dalam perspektif fraud. Jurnal Ekonomi Dan Bisnis, 16(1), 51-66.

McGuire, S. T., Omer, T. C., \& Sharp, N. Y. (2012). The impact of religion on financial reporting irregularities. The Accounting Review, 87(2), 645-673. https://doi.org/10.2308/accr-10206

Najahningrum, A. F. (2013). Faktor-faktor yang mempengaruhi fraud: Persepsi pegawai dinas provinsi DIY. Accounting Analysis Journal, 2(3), 259-267.

Pamungkas, D. I. (2014). Pengaruh religiusitas dan rasionalisasi dalam mencegah dan mendeteksi kecenderungan kecurangan akuntansi. Jurnal Ekonomi Dan Bisnis, 15(2), 48-59.

Permatasari, D., Taufikkurrohman, \& Kartika. (2017). Analisis faktor-faktor yang mempengaruhi terjadinya kecenderungan kecurangan (fraud) di sektor pemerintah (studi pada pegawai keuangan pemerintah kabupaten Banyuwangi). Jurnal Keuangan Dan Perbankan, 14(1), 37-44.

Prabowo, H. Y. (2014). To be corrupt or not to be corrupt Understanding the behavioral side of corruption in Indonesia. Journal of Money Laundering Contro, 17(3), 306-326. https://doi.org/10.1108/JMLC-11-20130045

Prabowo, H. Y., \& Cooper, K. (2016). Re-understanding corruption in the Indonesian public sector throughthree behavioral lenses. Journal of Financial Crime, 23(4), 1028-1062. https://doi.org/10.1108/JFC-08-20150039

Sindonews.com. (2015, June 12). KPK temukan 14 potensi permasalahan pengelolaan dana desa. Sindonews.Com. https://nasional.sindonews.com/berita/1012030/13/kpk-temukan-14-potensi-masalah-pengelolaan-danadesa

Singleton, T. W., Singleton, A. J., Bologna, G. J., \& Lindquist, R. J. (2010). Fraud Auditing and Forensic Accounting (4th ed.). John Wiley \& Sons, Inc.

Sukanto, E. (2009). Perbandingan persepsi auditor internal, akuntan publik, dan auditor pemerintah terhadap penugasan fraud audit dan profil fraud auditor. Fokus Ekonomi, 4(1), 13-26.

Taylor, J. (2018). White-collar crime and the law in nineteenth-century Britain. Business History, 60(3), 343-360. https://doi.org/10.1080/00076791.2017.1339691

Tuanakotta, T. M. (2007). Akuntansi Forensik \& Audit Investigatif. Lembaga Penerbit Fakultas Ekonomi Universitas Indonesia. https://doi.org/10.1016/j.clay.2015.06.031

Ubaidillah, M. (2019). Pengaruh tata kelola terhadap akuntabilitas pengelolaan dana desa dengan profesionalisme SDM dan integritas sebagai variabel intervening. Journal of Islamic Finance and Accounting, 2(1), 15-27. https://doi.org/10.22515/jifa.v2i1.1590

Urumsah, D, Wicaksono, A. P., \& Pratama, A. J. (2016). Melihat jauh ke dalam: Dampak kecerdasan spiritual terhadap niat melakukan kecurangan. Jurnal Akuntansi \& Auditing Indonesia, 20(1), 48-54.

Urumsah, Dekar, Wicaksono, A. P., \& Hardinto, W. (2018). Pentingkah nilai religiusitas dan budaya organisasi untuk mengurangi kecurangan? Jurnal Akuntansi Multiparadigma, $9(1), \quad 156-172$. https://doi.org/10.18202/jamal.2018.04.9010

Walker, A. G., Smither, J. W., \& DeBode, J. (2012). The effects of religiosity on ethical judgments. Journal of Business Ethics, 106, 437-452. https://doi.org/10.1007/s10551-011-1009-4

Wartaekonomi.co.id. (2019, May 21). Upaya dan Strategi Mewujudkan Desa Sejahtera Mandi. Warta Ekonomi. https://www.wartaekonomi.co.id/read228758/upaya-dan-strategi-mewujudkan-desa-sejahtera-mandiri

Weaver, G. R., \& Agle, B. R. (2002). Religiosity and ethical behavior in organizations: A symbolic interactionist perspective. The Academy of Management Review, 27(1), 77-97.

Wilopo, W. (2006). Analisis faktor-faktor yang berpengaruh terhadap kecenderungan kecurangan akuntansi: Studi pada perusahaan publik dan badan usaha milik negara di Indonesia. The Indonesian Journal of Accounting 
Research, 9(3). https://doi.org/10.33312/JJAR.163

Yansen, T. P. (2014). Revolusi Dari Desa: Saatnya Dalam Pembangunan Percaya Sepenuhnya Kepada Rakyat. Elex Media Komputindo.

Yuliani, S., Nadirsyah, \& Bakar, U. (2010). Pengaruh pemahaman akuntansi, pemanfaatan sistem informasi akuntansi keuangan daerah dan peran internal audit terhadap kualitas laporan keuangan pemerintah daerah (studi pada pemerintah kota Banda Aceh). Jurnal Telaah \& Riset Akuntansi, 3(2), 206-220.

Zulaikah, S., Nuraina, E., \& Styaningrum, F. (2018). Akuntabilitas dan transparansi anggaran pendapatan dan belanja desa Baluk kecamatan Karangrejo kabupaten Magetan. FIPAD: Forum IImiah Pendidikan Akuntansi, 6(2), 1-24.

Zulkarnain, R. M. (2013). Analisis faktor yang mempengaruhi terjadinya fraud pada dinas kota Surakarta. Accounting Analysis Journal, 2(2), 125-131. https://doi.org/10.15294/aaj.v2i2.2852 


\section{Appendix: Questionnaire Questions}

\section{The tendency to commit fraud}

Question

1. It is normal in my institution that, for a specific purpose, the cost is recorded higher than it should be.

2. It is not a problem for my institution if the recording of transaction evidence is carried out without an authorization from the competent authority.

3. It is normal for the agency where I work that, for a certain purpose, the purchase price of office equipment/supplies is recorded at a higher price.

4. It is natural in my agency for budget users to enter other needs that are not in accordance with the office equipment purchasing plan.

5. It is a natural thing in the agency where I work that budget users use blank receipts when purchasing office supplies.

6. It is not a problem for my institution if the purchased office equipment does not match the specifications required.

7. It is not a problem for my institution if a transaction is not supported by valid supporting evidence.

8. It is normal for the agency where I work to find expenses without supporting documents.

9. It is not a problem for my institution if the remaining budget is distributed to employees as a bonus.

\section{Asymmetry Information}

\section{Question}

1. I am more able to assess the potential influences of the external factors on the activities in my area of responsibility than is my supervisor.

2. I have better understanding on what can be achieved in my area of responsibility than does my boss.

3. I am more aware of potential performance in the area for which I am responsible than is my boss.

4. As the person in charge of the preparation of financial statements, I understand well the entire relationships between financial transaction data and financial report preparation process.

5. As the person in charge of financial statements preparation, I understand well the intricacies of making financial reports.

1. I always carry out all God's commands and stay away from all His prohibitions.

2. I regularly perform worship.

3. Every time I worship, I always mean it.

4. I fear God when I break His commandments.

\section{Organizational Culture}

\section{Question}

1. In my agency where I work, the leader is a role model in behaving.

2. In the institution where I work, a code of ethics has been implemented where organizational values and various ethical rules must be obeyed by the employees.

3. In the agency where I work, there have been ethical seminars and trainings on the standards of organizational demands that explain the prohibited practices and address the ethical dilemmas that may arise.

4. In the agency where I work, any unethical behavior that is committed will be sanctioned.

\begin{tabular}{l} 
Regulatory Enforcement \\
Question \\
\hline 1. In the agency where I work, there are legal rules that apply. \\
2. In the agency where I work, I feel that the officials are responsive in handling the regulatory violations. \\
3. In my institution where I work, the agency's operational activities are carried out in accordance with \\
the standards and regulations set by the agency and the government. \\
4. In the agency where I work, all employees come and go home on time. \\
5. In the agency where I work, all employees do their jobs according to their respective responsibilities.
\end{tabular}

